\title{
Socially Responsible Organisational Governance in the Public Sector
}

\author{
Gita Lasytè \\ Mykolas Romeris University \\ Ateities g. 20, LT-08303 Vilnius, Lithuania \\ cross'ef $^{\text {http://dx.doi.org/10.5755/j01.ppaa.19.3.27713 }}$
}

\begin{abstract}
The present paper aims to examine the theoretical assumptions of socially responsible organisational governance in the public sector. In public authorities, corporate social responsibility is a relatively new phenomenon. Therefore, the paper focuses on the interaction between social responsibility and the New Public Governance. The article puts forward the assumption that the principles of governance of public goods and public services provided by the public sector are very close in content to the concept of social responsibility. The goal of the public governance process is efficiency and effectiveness not only in public administration institutions but also in building a welfare society. In this context, New public governance is in line with the principles of social responsibility. The similarities between the new public governance and social responsibility can be recognised in an understanding the values, processes and elements the primary standards of which are accountability, openness, efficiency, responsibility, compliance with procedural norms, division of power (involvement of stakeholders). The article also discusses the concept and characteristics of corporate social responsibility and provides criticism on the CSR phenomenon.
\end{abstract}

Keywords: Corporate Social Responsibility, Public Sector, New Public Governance, Organizational Governance, Stakeholders.

Raktažodžiai: organizacijos socialine atsakomybè, viešasis sektorius, Naujasis viešasis valdymas, organizacijos valdymas, suinteresuotosios šalys.

\section{Introduction}

Over the past few decades, the processes taking place in the global environment have influenced the governance actions of modern organisations. The fast-changing economic and social environment, the rapid growth of information technologies, the depletion of natural resources and climate change have been having a crucial impact on the activities of organisations. Given such a dynamic environment, researchers in the field of science of Social Sciences and study branch of Management have begun to extensively discuss the importance of corporate social (CSR) responsibility. In other words, due to the negative consequences of globalisation, CSR is becoming even more critical and turns into a serious tool that fosters the increase of competitiveness in the $21 \mathrm{st}$ century (Jamali and Dirani, 2014; Global Leadership Bulletin, 2015). Corporate social responsibility is relatively a new concept. However, it is already classified as one of the essential concepts of modern management (Bagdonienè and Paulavičienè, 2010; Fontaine, 2013; Berber et al., 2014). The fundamentals of corporate social responsibility lie in the voluntary and non-statutory application of the sustainable development of principles of its activities. They include corporate world view, policies and practices, that manifest the company undertakings when it integrates environmental and social aspects into its activities. Also when it applies the values of respect for man, society and the environment in the relations with all members of society, business and government representatives (Clegg, Bailey, 2008; Grundey, 2008; Desur, 2013; Korsakienè and Marcinkevičius, 2013; Laurinavičius and Reklaitis, 2011; Išoraitè, 2013; Jha, Singh, 2016). 
It should be noted that corporate social responsibility has started in the private sector. This was due to business development, which promoted the adoption of socially responsible decisions in the areas of risk management, cost-saving, access to capital, client and partner relations, as well as innovation (Weber, 2008; Žičkienè, 2015). Usually, large organisations which employ substantial numbers of employees or provide goods or services to an extensive consumer market are interested in corporate social responsibility (Simanavičienė, Kovaliov and Šubonyte, 2011). However, it should be noted that social responsibility has to be exercised not only in business but also in any organisation. The guidelines of the social responsibility standard ISO 26000: 2010 specify that the principles of social responsibility have to be applied not only to businesses but also to public and municipal authorities and institutions. ISO 26000 is a standard for social responsibility guidelines for all types of organisations, both public and private. On the other hand, in modern management theories and public discourse, there is a growing interest in CSR, however, in Lithuania, the principles of social responsibility have been slowly integrated into the policies and practices of public sector organisations. In general, there is a worldwide shortage of comprehensive research on socially responsible organisations in public administration institutions. Therefore, the study presented in the article is of scientific novelty.

Theoretical and practical aspects of corporate social responsibility, the development of this concept, the significance of CSR for the organisational governance are widely discussed topics in the works of both Lithuanian and foreign researchers. In theoretical interpretations, CSR is often defined as one of the managerial improvement paradigms in business organisations (Matten and Moon, 2005; Albareda et al., 2006, 2007; O'Riordan and Fairbrass, 2008; Gao, 2009; Barrett, 2009; Carroll ir Shabana, 2010; Giannarakis ir Theotokas, 2011; Virvilaite and Daubaraitė, 2011; Balčiūnienė and Kazlauskaitė, 2012; Schmeltz, 2012; Potašinskaitė and Draugelytė, 2013; Išoraitė, 2013; Korsakienė and Marcinkevičius, 2013; Bakič, Kostič and Neškovič, 2015; Hawrysz and Foltys, 2015; Dankova et al., 2015; Giannarakis, 2016; Baden, 2016; Skačkauskienė and Valentinovič, 2016; Martínez et al., 2016; Jamali and Carroll, 2017; Frederiksen, 2018; Nikolić and Zlatanović, 2018; Jamali and Karam, 2018; Carroll and Brown, 2018; Mayer, Tost and Wellman, 2018; Dias et al., 2019). The analysis of the scientific literature on the public sector confirms that the topic of CSR in public authorities is not of great relevance (Hawrysz, 2015; Ileana, 2015; Formánková et al., 2017; Smaliukiené, 2005; Marčinskas and Seiliūtè, 2012; Streimikienè and Pušinaitė, 2009; Guogis and Gudelis, 2009; Vilkė, 2011; Tauginienè, 2013).

Social responsibility in the public sector is often equated with corporate social responsibility (Ates, Büttgen, 2011). Presumably, it is due to the high level of ambiguity inherent in CSR. In other words, there is no straightforward systemic approach that would clearly build up specific ways and means to implement the CSR concept. However, it is essential to understand that the differences between the public and private sectors are determined not only by a culture of values and landmarks but also by the principles of governance of public goods and services. Therefore, in order to better understand and evaluate the public sector corporate social responsibility, its causes and content elements and then to predict the processes and possible consequences, it is necessary to examine the theoretical aspects of public sector CSR.

The aim of this article is to analyse the theoretical aspects of social responsibility in public sector organisations. To achieve this aim, the following tasks have been set: to characterise the theoretical aspects of social responsibility from a managerial point of view, to reveal the links between the New Public Governance and social responsibility; to analyse the peculiarities of social responsibility implementation in the public sector. The applied research methods involved the analysis of scientific literature and comparative analysis that have been employed to report the attitudes of various authors towards the Corporate Social Responsibility, as well as construe conceptual notions. Logical generalisation and critical evaluation of the collected material was also used. 


\section{Theoretical aspects of Corporate Social Responsibility}

The term Corporate Social Responsibility was formed in the 1950s. Until then, the scholars who were working in major economic theory areas had approached this issue in a highly fragmented way. Over time, social responsibility has become an object of scientific research and a part of business practice. The era of CSR started around 1950, with the concept developed by the US economist H. R. Bowen. This scientist is often called the "father of corporate social responsibility" (Farcane, Bureana, 2015; Hamidua et al., 2016). In his famous publication "Social Responsibilities of the Businessman" (1953) H. R. Bowen defined social responsibility as the commitment of entrepreneurs to implement the strategies and decisions and follow the policies that are preferred and valued by the society (Bowen, 1953, 2013). The author opposed the capitalist business ideology, for which the maximisation of profits and the increase of company indicators were the most important. There was very little respect for employees, and they were not treated fairly. Thus, the proponents of social responsibility encouraged the development of philanthropic programs for organisations to improve the community life, promote environmental protection and enhance sustainable development (Haerens, 2014). It is essential to note that H. R. Bowen's definition has become the basis for the modern concept of CSR. In other words, since this period, the changes have been witnessed within the business environment and the nature of socially responsible initiatives.

In the historical context of the CSR concept development, the model of the social responsibility pyramid developed by the researcher Archie B. Carroll $(1979,1991)$ is of considerable scientific importance. The pyramid comprises four responsibilities that are linked by hierarchical relationship: economic, legal, ethical, and philanthropic (Unterberger et al., 2018). This theory integrates the decisions and policies of social responsibility organisations into a whole. Economic responsibility is defined as the responsibility to develop profitable activities, increase shareholders' return on investment, ensure safe and well-paid work for employees and provide quality goods to consumers at a reasonable price. Legal responsibility includes the application and enforcement of legal regulations in order to comply with the rules at the legal level. The main precondition for socially responsible companies to remain in the market and continue their activities is to follow and adhere to the law and act more responsibly than required by law. Ethical responsibility is related to voluntary company activities to do what is right and fair, though not legally binding. This fosters companies not to harm society and the environment. Philanthropic responsibility at the top of the pyramid model encourages companies to contribute their resources to the increase of the well-being of society and the improvement of the quality of life (Thorne et al., 2008; Pilinkiene et al., 2018). It should be noted that non-passive philanthropic responsibility does not profit companies. However, it creates a socially responsible environment in a company, which encourages employees to work more efficiently and achieve higher results (Tripathi and Bain, 2013; Stachowicz-Stanusch, 2017).

In the academic literature, the concept of corporate social responsibility has not been made very clear so far and is still the subject of debate (Rahman, 2011). It has been observed that early definitions of CSR are somewhat contradictory, too narrow, complex, or assigned to only one category for which CSR is responsible (Park and Levy, 2013; Bauman and Skitka, 2012; Jurek, 2014; Carter, 2014; Alhaddi, 2015). Budrionyte (2014) emphasises that the dynamics of the concept CSR directly depends on the time period and the established common norms and views. The term CSR is still multifaceted and changing today (Glavo and Kelley`a, 2014). It is also interpreted in different ways because the implementation of CSR principles in companies is an integral process that combines both company policy (declaration of future vision, goals, values, aspirations) and practice (measures of establishing economic, social and public attitudes in activities) (Gineitienè and Žiogelytė, 2010). With respect to this, it is possible to distinguish the different descriptions of corporate social responsibility used by theorists and practitioners. They are: "business social responsibility", "company social responsibility", "corporate social responsibility", "sustainable corporate development", "corporate citizenship", "corporate responsibility", "common social responsibilities", corporational social responsibilities", "corporate social responsibilities". It is noted that the concept of CSR has previously been equated to the following terms "corporate citizenship", "business ethics", 
"corporate governance", "sustainable development", "corporate accountability", "corporate social performance", "stakeholder theory", etc. (Potašinskaitė and Draugelytė, 2013; Jurek, 2014).

According to Bagdonienè and Paulavičiene (2010), corporate social responsibility is the ideology, policy and practice of companies. It manifests the performance of companies, when social and environmental issues are included in company activities voluntarily and when guidelines of respect for people, society and nature are observed. Corporate social responsibility is understood and recognised as a set of principles and initiatives that improve corporate governance and reporting, bear responsibility for the impact on the environment and society. Modern business must also focus on human capital because profitability is not the only indicator. In other words, such a model of organisational governance has to reconcile commercial actions with social goals and ethically take into account the needs of all stakeholders (Šimanskienè and Paužuolienè, 2010; International Chamber of Commerce, 2011; European Commission, 2014; Jeenbaeva, 2015; Leitoniené and Šapkauskienè, 2016; Allen and Craig, 2016; Khan, 2017). In addition, both theoretical and practical scientific studies of recent times have confirmed that CSR is moving from an abstract idea to a concept which is being included into the activities of more and more organisations (Banyte, Brazdžioniené, Gadeikiené, 2010). The concepts of CSR presented above favour the opinion that most definitions primarily emphasise the issues that include environmental, social, economic, stakeholder aspects as well as voluntary performance and protection of human rights in the company activities (Welford, 2005; Dahlsrud, 2006). Taking this into account, it follows that organisations sustaining a commitment to exercise socially responsible initiatives in their activities should start from the implementation of these socially responsible initiatives in their performance (Seiliūtè, 2013).

Another important consideration is that socially responsible organisations are particularly valued for their impact on the environment as a whole. In other words, a socially responsible organisation not only contributes to the environmental protection but also shapes better living conditions in the society, improves the working conditions of employees, attracts and retains the best specialists, carries out transparent activities (Lin, 2010; Huang, 2013; Šimanskienė and Paužuolienė, 2015; Bediako, 2017). This enables organisations to achieve better performance results, gain a competitive advantage and earn the trust of all stakeholders (Skačkauskiene,, Valentinovič, 2016; Wang, 2017; Romi et al., 2018). The analysis of the scientific literature has demonstrated that most researchers unanimously emphasise the importance of stakeholders in the context of CSR. Stakeholders are considered to be one of the key components in the organisation. Companies would not be able to achieve their goals without the support of their stakeholders (Lee, Lancendorfer, \& Reck, 2011). Therefore, organisations need to make every effort to reconcile different economic, legal, ethical and social responsibilities towards stakeholders. In other words, the integration of CSR principles into a company performance exhibits the values of the organisation. This is a legitimate and compelling way to attract and retain good employees, increase job satisfaction, and boost employee productivity (Oshin-Martin, 2017). According to Inyang, Awa, and Enouh (2011), company employees make one of the most important entity in the performance of an organisation as their decisions and activities are the driving factors to promote and implement social responsibility initiatives. It has been found that CSR activities that promote employee participation involvement increase employee motivation (Majer, 2013; Rodeia, 2017). With respect to this, it can be affirmed that regardless of the difference in needs and aspirations, all stakeholders have a significant and direct impact on the implementation of CSR (Yu and Choi, 2014). On the other hand, the implementation of CSR can be launched at the request of employees or other stakeholders, rather than at the voluntary discretion of the organisation itself (Yuan, Bao, \& Verbeke, 2011).

However, the analysis of the concept "corporate social responsibility" as an object of research has also received negative criticism. The ideology of CSR has been criticised and considered as opposing to the basic principle of business which is the increase in profit. Business theorists argue that the implementation of corporate social responsibility is not financially viable and is even detrimental to companies. Responsible work manner is very costly and can negatively affect the company indicators of competitiveness (Kontautienè, 2016). Besides, public indignation is also 
frequent because of rising prices for services and goods, or additional bureaucracy and the increase of operating costs, unequal assessment criteria (due to differences in a company performance) (Croitor, 2014; Geethamani, 2017). However, it has been observed that these approaches are criticised for being overly focused on the internal resources of an organisation and without any consideration of the external factors. Researchers acknowledge that in response to technological advances, the transformational evolution of corporate social responsibility prompts the formation of new business structures and strategy parts (Agudelo et al., 2019). Due to the above-mentioned issues, the question arises whether compliance with the law is a sufficient indicator of the responsible business and whether activities that have a negative impact on the environment can be considered as irresponsible, although the law does not stipulate that (Žičkienè and Kavaliauskienė, 2015).

\section{Characteristics of Socially Responsible Public Governance}

Although the issue of social responsibility has extensively been researched and analysed in the scientific literature, there is still very little research and a few discussions on the impact of social responsibility towards the New Public Governance. New Public Governance as the model of public administration is also influenced by evolutionary processes. With a view to the continuous renewal of public governance institutions and provision of strategic directions and tendencies of governance reform and modernisation, new governance methodologies are being hunted for, and performance instruments are being improved (Raipa, 2014). In other words, traditional governance models and methods are becoming ineffective. Therefore, new initiatives need to be taken to address the challenges posed by uncertainty and complexity issues (Christensen, Lagreid, 2007; Pollitt, Bouckaert, 2011). For these reasons, in the period of recent decades, new concepts of public governance came out both in the scientific literature and in the European Union documents. They have been termed as Good Governance, Open Governance, Collaborative Governance, Smart Public Governance. The New Public Governance was a precondition for the emergence of these concepts. The concepts presented above suggest that the characteristics of public administration organisations are under the change process and are undergoing transformations.

In this context, the change in public administration practices presupposes that social responsibility could also be seen as a governance model. On the other hand, if we realise that the public sector is "the governance of people for the benefit of people" and corporate social responsibility is organisational attention towards the society and the well-being of its people, it is necessary to assume that public sector activities are in their essence the implementation of the social responsibility (Rybnikova and Toleikienè, 2015). According to Guogis (2006), social responsibility can help achieve both social and economic justice in the private sector; however, the public sector provides public goods. Thus, it can be understood as a self-sustaining process. In other words, the principles of CSR must be observed with respect to public sector mission and the type of performance. The question arises as to whether social responsibility can be distinguished as a separate concept of public governance or even a paradigm with certain specific characteristics, and how it would be possible then to define what public governance could be socially responsible. Socially responsible governance should include the concepts of social responsibility that analyse social responsibility as a result of the agreement between the state and the society, which are strongly influenced by decisions made by public authorities, as well as legitimacy, transparency, accountability and efficiency (Sherer, Palazzo, 2011). Meanwhile, the social responsibility of business organisations is understood as a company policy and practice when the company voluntarily integrates social, environmental and transparent business principles into its performance internal processes and external relations in accordance with laws, international agreements and agrees on norms of conduct (Vilutyte், 2013).

Thus, it is assumed that the New Public Governance raises social responsibility goals. The New Public Governance rests on the importance of citizens, their involvement and participation, absence of corruption, strong democracy, transparency, responsibility and accountability, interinstitutional cooperation and is considered to be a key concept for conceptualising scientific discussions and public governance practices (Navarro-Galera et al., 2014; Visockyte, 2012; 
Jonikaite et al., 2016). This means that the public governance system is a socially responsible system. The New Public Governance raises new requirements for the implementation of corporate social responsibility in institutions at all levels. In other words, the ideology of the New Public Governance attempts to establish much higher standards and criteria of social responsibility of organisations and public authorities. These standards enable the participation of citizens and social groups in the preparation and implementation of public decisions at various levels of governance (Raipa, 2011). The similarities between the New Public Governance and social responsibility can be viewed in an understanding of the values, processes and elements. Their primary standards are accountability, openness, efficiency, responsibility, compliance with procedural norms, division of powers (involvement of stakeholders). Such an interpretation is considered to be the ideological basis of the new dichotomy of the New Public Governance and social responsibility. However, social responsibility as a dimension of public administration acquires the sense when the characteristics of a socially responsible organisation are integrated into the structures and processes of the system of public administration institutions.

\section{Corporate Social Responsibility Concept in the Public Sector}

Public administration theorists, political scientists, and management professionals argue that the necessity for management of changes driven by globalisation processes shapes the development of public governance reforms to create new visions of governance evolution that encompass all types and levels of public sector structures (Davies, 2007; Raipa, 2014). It is recognised that the government of a country has to find appropriate ways to organise governance and public sector activities that address relevant public governance issues, e. g. sustainable development, public sector integrity and increase of people's trust in their government (Gaule, 2014). The public sector has also to pursue the implementation of principles and standards of social responsibility. An essential condition is that public authorities, as a public governance entity, need to create a favourable environment for the development of CSR, as it serves the public interest. Interestingly, S. Zadek is considered to be the first to define the role of government in the context of corporate social responsibility. The mentioned researcher described how national governments engage in the development of CSR while giving it new opportunities. Zadek called this phenomenon the third generation of CSR implementation when the support of governmental authorities becomes a fundamental condition for the implementation and support of CSR (Albareda et al., 2008).

With respect to the study "Promotion of Social Responsibility of State-Owned Enterprises" conducted in 2019, it was concluded that Lithuanian state institutions currently do not sufficiently apply the principles of social responsibility in their activities. Most institutions do not have a clearly spelt out and approved sustainability policy, they do not build their activities on globally recognised standards, and they do not publish sustainability information on their website. Besides, CSR is often understood too narrowly and as a single initiative in the form, for example, of philanthropic activities or provision of support. Though CSR-related project activities and initiatives are already underway in Lithuania, they do not always involve public institutions and are mostly focused on private businesses. In addition, a new phase of public governance improvement will commence with the approval and launch of the Public Governance Improvement Program 2012-2020. Therefore, the impact of social responsibility on the success of the company is definitely going to increase in the future. The needs of individual consumers for responsibly produced goods and services are growing, as well as the general understanding that everyone must ensure the full-fledged coherence of the society (Public company "Invest in Lithuania", 2019).

It has to be noted that research on foreign organisations specifies a variety of possible reasons why foreign companies do not apply CSR. The following reasons have been identified:

1. Lack of information. Public governance institutions do not have enough information about the benefits of CSR. Besides, there is an unsubstantiated prejudice towards CSR as a solution that requires investment, and does not necessarily pay off; 
2. Lack of resources. There are no extra funds to invest in the implementation of CSR and coordinate related activities. Also, there is a lack of expertise within the organisations;

3. Lack of good examples. Due to the low implementation of CSR by other companies, companies do not feel peer pressure and are not aware of the best possible ways to do so;

4. Lack of evaluation. There are no incentives to implement CSR, as the efforts of the bestperforming companies are underestimated;

5. Other priorities. Public authorities may prioritise the solution of other problems or fulfil only narrowly defined responsibilities (Stubbs, Higgins, \& Milne, 2013).

Social responsibility should be understood in the public sector as a role model, promotion and implementation of sustainable development, promotion of partnership/dialogue with stakeholders, increase of the overall competitiveness in the country. The practice of foreign countries shows that governments and their institutions can often promote social responsibility through public procurement (applying the criteria of "green", "social", "sustainable" procurement), as well as by setting an example for public institutions, using resources sparingly and managing their performance efficiently, motivating employees to perform their assigned functions responsibly, ensuring greater transparency in public procurement, implementing joint partnership projects with stakeholders, etc. The implementation of these actions would significantly increase the transparency and credibility of public sector activities, in particular by earning the trust of businesses and society in the public authorities (Model Plan for Implementing Corporate Social Responsibility in Public Institutions, 2012).

Researchers Fox, Ward, Howard (2002) strongly emphasise the key categories of government and state institutions in the development of CSR. They are:

- Mandating. It refers to legal obligations. Mandating means that governments need to define at different levels the minimal business performance standards enshrined in the legal framework. Mandating cases are, for instance, the regulation of working conditions by defining maximum working hours, occupational safety and health requirements, environment protection law, etc.;

- Facilitating. It refers to various guidelines, funding mechanisms, facilitation of favourable conditions. Facilitating for public sector organisations relates to the aim to improve company social and environmental performance by introducing initiatives and creating a favourable climate for the development of CSR. The process may include such CSR promotion measures as funding of research, publicity campaigns, information dissemination, training and awareness-raising projects. Public policy institutions can also promote a proactive CSR market by creating tax incentives, conducting public procurement, employing investment and funding leverage. Promote dialogue between all stakeholders at the national level in order to reconcile different interests;

- Partnering. It refers to collaboration and mutual dialogue of stakeholders. Strategic partnerships can provide extra energy and significant input to the public or private sector and civil society in addressing complex social and environmental challenges. In general, public authorities have the opportunity to reconcile the roles of different stakeholders and plan a policy direction, a solution that would include and combine capabilities to complement existing core competencies;

- Endorsing. It refers to instruments and publicity. Political support and public sector backing of the CSR concept, in particular of the initiatives related to CSR, manifest the fourth public sector category in the typology presented. Endorsing may take a variety of forms, from ad-hoc meetings to policy papers or award schemes that support innovative CSR initiatives or recognise the efforts of individual companies;

- Demonstrating. It refers to leading by example. With regard to the importance of demonstrating the example, the fifth category was created to facilitate the understanding of the role of the Government and its institutions in the development of CSR. This category includes such issues as the safeguard of integrity in the fight against corruption, the 
increase of the transparency of public institutions in their relations with external stakeholders. In addition, public authorities have to apply CSR standards in their activities, for example through the "demonstration" of the effect of public procurement, the organisation of tenders, the responsible use of resources, etc. (Unido,2007).

It should be noted that public administration institutions can implement such activities in a variety of forms and scopes - from raising public awareness on social responsibility and developing the capacity of companies and other organisations in the field of CSR, from the launch of sponsorships and charitable campaigns, solution of economic, social and environmental issues and promotion of transparency measures in certain business sectors, from attracting socially responsible investments to the most important measure which is setting the example by the governmental authorities themselves (sustainable public procurement, implementation of management systems within the organisation, etc.) (Feasibility Study of Implementing Corporate Social Responsibility in State Institutions, 2012).

In order to have a comprehensive understanding of the principles of social responsibility in the public sector, it is important to review the good practices of foreign countries. In general, it is useful to evaluate the practices applied by other countries in the world, since the knowledge acquired can help to adapt the effective social responsibility governance systems and management methods already in place. An interesting fact is that, back to Communication adopted in 2006, the European Union set itself the goal of making Europe a model of social responsibility, thus, demonstrating the interest in the implementation of the concept of social responsibility in business organisations as well as in the public sector (Feasibility Study of Implementing Corporate Social Responsibility in State Institutions, 2012).

Thus, the Schiphol Group company, which operates various airports in the Netherlands, pursues to integrate day-to-day operations into its activities. The president of the company is responsible for the implementation of social responsibility standards, and he shares this responsibility with other members of the board. Each member of the board is in charge of a particular area of CSR activity. The direction and policy of CSR are shaped by the top management that is advised by managers, the Public Affairs and Responsibility Committee as well as the Supervisory Board. The achievement of CSR objectives is also linked to the remuneration system (Schiphol Group Annual Reports, 2010, 2011). Another case is of a Swedish and Danish government-owned postal and logistics company PostNord AB. This company endeavours to provide the services in a sustainable way with the least possible environmental impact: more than $60 \%$ of transport deliveries between distribution points is conducted by rail; whenever possible electric cars or bicycles are employed; all the premises used by the company save resources (electricity and heat energy); efforts are made to minimise the generation of waste and to recycle the resulting ones (PostNord, 2019). In the UK, Her Majesty's Government has ruled that subordinate institutions must have a Volunteering policy which may include a provision for voluntary work, from 1 to 5 days per year for which a fee is paid. It is called Charitable Payroll Giving. Most institutions publish the information about volunteering opportunities within their organisation through the intranet, internal advertisements or publications. Also, these organisations often have either formal or informal collaboration with organisations that provide the volunteering opportunity, invite volunteers. The Cabinet Office plays a key role in designing a more unified approach to volunteering activities of civil servants (UK Government Social Responsibility Report, 2011). In Latvia, the Ministry of Environment attempts to promote the development of CSR in the regions by designating "Apple" nominations to the regional municipalities for their appropriate sustainable development policy. In 2005 in France, the municipality of Angers appointed a legal adviser in the field of green procurement at the Public Procurement Enforcement Center. The task of that advisor was to specialise in and be responsible for the development of socially responsible public procurement so that such a practice would become continuing and general in municipal procurement. Thus, it can be asserted that the examples of good practice implemented in European countries prove that when the CSR promotion policy is adequately designed, adapted to the situation, systematically implemented, monitored and improved it becomes effective and helps to achieve long-term comprehensive goals of sustainable development. (Feasibility Study of Corporate 
Social Responsibility in State Institutions, 2012). Lithuanian public governance institutions have to evaluate the practices of other countries and monitor their dissemination. It is the dissemination of good practices that will help public authorities to enhance their visibility and image both internally and externally as well as increase the efficiency of their performance, etc.

The analysis of different research works shows that corporate social responsibility in the private sector, as well as the public one, is understood as the appropriate, ethical and transparent conduct of an organisation that is aligned with environmental, economic and social issues. A socially responsible organisation is concerned about the needs of stakeholders and contributes to the wellbeing of society. In the public sector, corporate social responsibility refers to one of the strategies for the development of the welfare state. It is important that the public administration implements state governance and the provision of public services; it also regulates the activities of private businesses; therefore, the implementation of social responsibility becomes especially important. Taking into account the above-mentioned good practices implemented in other countries, Lithuania needs to implement the principles of social responsibility which would improve the performance of the Lithuanian public administration system, and at the same time would promote the implementation of good practices.

\section{Conclusions}

1. The analysis of the scientific literature has shown that the concept of corporate social responsibility is a broad-spectrum process that is shaped by the moral, legal, political and economic relations between the organisation and the society. Ethical standards, consideration of stakeholders' needs and the implementation of environmental protection principles are of key importance in this concept. In other words, it is the paradigm for the development of corporate social responsibility areas. The social provisions of an organisation become more important than economic benefits. The concept of CSR builds up a new approach towards the organisation as a basis for the increase of public welfare. It has been discovered that there are quite a few different definitions of CSR as well as theories that summarise them. However, the key aspects of this phenomenon that was introduced by the 20th-century authors Bowen and Carroll apply to date. Compared to other EU countries CSR in Lithuania is a relatively new phenomenon, and it is mainly developed in the private sector.

2. The identification of social responsibility dimensions illustrates that with respect to the content, this concept is very close to the concept of public administration. The goal of the public governance process is efficiency and effectiveness not only in public administration institutions but also in building a welfare society. In this context, New Public Governance is in line with the principles of social responsibility. On the other hand, the New Public Governance provides public goods and, therefore, it can be understood as an inherently socially responsible process. It can be assumed that such characterisation of the features identified leaves open the question of whether social responsibility can be recognised as a specific concept of public governance or even a paradigm.

3. The phenomenon of social responsibility has been developing and changing, and thus acquired a broader meaning. The CSR principles were started to be applied not only to businesses but also to public sector institutions. Although this issue has been little researched, and there are a few discussions on this subject, it is recognised that public authorities also need to follow social responsibility principles. Socially responsible public sector organisations are characterised by more transparent governance, more sustainable activities, and greater public trust. However, the implementation of social responsibility in state institutions is deterred by the lack of information, resources, good practices and evaluation.

\section{References}

1. Agudelo, L. M. A., Johannsdottir, L., Davídsdottir, B. 2019. A Literature Review of the History and Evolution of Corporate Social Responsibility. International Journal of Corporate Social Responsibility, 4 (1), doi:10.1186/s40991-018-0039-y. 
2. Albareda, L., Lozano, J. M., Tencati, A., Midttun, A., Perrini, F. 2008. The Changing Role of Governments in Corporate Social Responsibility: Drivers and Responses. Business Ethics: A European Review, 17(4), 347-363.

3. Alhaddi, H. 2015. Triple Bottom Line and Sustainability: A Literature Review. Business and Management Studies. DOI: 10.11114/bms.v1i2.752.

4. Allen, M. W., Craig, C. A. 2016. Rethinking Corporate Social Responsibility in the Age of Climate Change: A Communication Perspective. International Journal of Corporate Social Responsibility, 1(1), 1.

5. Ates, Z, Büttgen, M. 2011. Corporate Social Responsibility in the Public Service Sector: Towards a Sustainability Balanced Scorecard for Local Public Institutions. Journal of Public and Nonprofit Services 34(3): 346-360.

6. Atkočiūnienè, Z., O., Gineitienè, Z., Žiogelytė, L. 2010. Regionų plètra: Žmogiškujų išteklių potencialas. Viešasis Administravimas, 25-26(1-2), 44-52.

7. Bagdonienè, D., Paulavičienè, E. 2010. Socialinès atsakomybès ir organizacijos vadybos sistemos integravimas. Ekonomika ir vadyba, 15, 366-373.

8. Bagdonienè, D., Paulavičienè, E. 2010. Socialinès atsakomybès ir organizacijos vadybos sistemos integravimas. Ekonomika ir vadyba, 15, 366-373.

9. Banyte, J., Brazioniene, L., Gadeikiene, A. 2010. Expression of Green Marketing Developing the Conception of Corporate Social Responsibility. Inžinerinè Ekonomika-Engineering Economics, Kaunas: KTU, Nr. 21.

10. Bauman, C., W., Skitka, J., L. 2012. Corporate Social Responsibility as a Source of Employee Satisfaction. Research in Organisational Behavior, 32, 63-86.

11. Bediako, O. B. 2017. The Impact of Corporate Social Responsibility on Customer Loyalty a Case study of Stanbed Tours ky. International Business. 1-70.

12. Berber, N., Stangl, Susnjar, G., Slavic, A., Baosic, M. 2014. Relationship Between Corporate Social Responsibility and Human Resource Management - as New Management Concepts in Central and Eastern Europe. Inzinerine Ekonomika-Engineering Economics, No. 25(3), p. 360-369.

13. Bowen, H. 1953. Social Responsibilities of the Businessman. New York: Harper.

14. Bowen, H. R. 2013. Social Responsibilities of the Businessman. Lowa: University of Lowa Press. ISBN: 978-1609381967.

15. Budrionytè, R. 2014. Informacijos apie įmonès socialinę atsakomybę pateikimas finansinèse ataskaitose: nauda ir galimybès. Buhalterinès apskaitos teorija ir praktika. 15, 63-75.

16. Christensen, T., Lagreid, P. 2007. The Whole-of-Government Approach to Public Sector Reform. Public Administration Review, 67 (6): 1059-1066.

17. Clegg, S. R., Bailey, J. R. 2008. International Encyklopedia of Organization Studies. Sage Publication, 1, 838-1214.

18. Croitor, E. 2014. Ethics of Responsibility? Some Postmodern Views. Procedia - Social and Behavioral Sciences, 149, 253 - 260.

19. Dahlsrud, A. 2007. How Corporate Social Responsibility is Defined: an Analysis of 37 Definitions. Corporate Social Responsibility and Environmental Management, 15(1), 1-13.

20. DESUR. 2013. İmonių socialinè atsakomybè: gerosios praktikos pavyzdžiai ir rekomendacijos http://www.desur.eu/wpcontent/uploads/2013/02/GuideGoodPracticesandRecommendations.pdf [2020-03-14].

21. Ekonominès konsultacijos ir tyrimai. 2012. Pavyzdinis organizacijų socialinès atsakomybès diegimo

22. Farcane, N., Bureana, E. 2015. History of Corporate Social Responsibility Concept. Annales Universitatis Apulensis Series Oeconomica, 17(2), 31-48.

23. Fontaine, M. 2013. Corporate Social Responsibility and Sustainability: The New Bottom Line? International Journal of Business and Social Science Vol 4 No 4; April 2013. 
24. Gaulè, E. 2014. Sumanus viešasis valdymas: samprata ir dimensijos. Viešoji politika ir administravimas, T. 13, Nr. 3, 372-385.

25. Geethamani, S. 2017. Advantages and Disadvantages of Corporate Social Responsibility. International Journal of Applied Research, 3(3), 372-374.

26. Global Leadership Bulletin. Sustainability Is Key to Survival. http://www.standardizations.org/bulletin/?p=710 [2020-03-14]

27. Grundey D. 2008. Applying Sustainability Principles in the Economy, Technological and Economic Development of Economy, 14(2): 101-106.

28. Guogis A. 2006. Kai kurie korporatyvinès socialinès atsakomybės ir socialinio teisingumo aspektai. Viešoji politika ir administravimas, Nr. 18, p. 73-77.

29. Haerens, M., Lynn, M., Zott, M. 2015. Corporate Social Responsibility. Farmington Hills, MI: Greenhaven Press, 2014. Opposing Viewpoints. Opposing Viewpoints in Context. Web. 8 Dec. 2015.

30. Hamidua, A. A., Haronb, H. M., Amranc, A. 2016. An Overview on the Historical Background and Sustainability Models of Corporate Social Responsibility. School Of Social Science: USM Malaysia. 24-33.

31. Huang, K. 2013. An Alternative Conceptualisation of Corporate Social Responsibility - a Comparison of SME in China and UK. Norwich Business School. 1-308.

32. Inyang, B. J., Awa, O. H., Enouh, O. R. 2011. CSR-HRM Nexus: Defining the Role Engagement of the Human Resources Professionals. The Special Issue on Contemporary Issues in Business and Economics, 118-126.

33. Išoraitè, M. 2013. Alaus gamybos įmonių socialinès atsakomybės tyrimas. Verslo sistemos ir ekonomika 3 (2): 248-265.

34. Yu, Y., Choi, Y. 2014. Stakeholder Pressure and CSR Adoption: the Mediating Role of Organizational Culture for Chinese companies. The Social Science Journal.

35. Yuan, W., Bao, Y., Verbeke, A. 2011. Integrating CSR Initiatives in Business: an Organising Framework. Journal of Business Ethics, Vol. 101, No. 1, 75-92.

36. Jamali, D., Dirani, A. 2014. Synergies of CSR and Diversity Management: a Converging Agenda. In M. Karatas-Ozkan, K. Nicolopoulu, M. F. Ozbilgin (Ed.), Corporate Social Responsibility and Human Resource Management: A Diversity Perspective, (pp.51-65). Cheltenham: Edward Elgar Publishing Limited.

37. Jeenbaeva, J. I. 2015. Green Enterprise Workers' Participation in Social Change Induced by Climate Discourses: Institutionalisation of the Global Policy Clubs' Green Discourses at the Local Level. Dissertation in Local Development and Global Dynamics, Doctoral School in Social Sciences, University of Trento, Trento, Italy.

38. Jha, B. K., Singh, R. 2016. Corporate Social Responsibility in India. International Journal of Higner Education Research and Development 1(1): 1-8. ISSN-2456-2629.

39. Jonikaite, E., Juknevičienè, V., Mikolaitytė, J. 2016. Naujojo viešojo valdymo transformacija: sumanumo dimensija. Ekonomika ir vadyba: aktualijos ir perspektyvos. 20161 (38). 39-48, ISSN 1648-9098.

40. Jurek, M. 2014. The Genesis and Evolution of CSR Self-Regulation with Special Reference to the Case of Financial Institutions. Fessud Financialisation, Economy, Society and Sustainable Development. Working Paper Series, 70.

41. Khan, M. A. 2017. To Evaluate the Role of CSR (Corporate Social Responsibility) Programs on the Buying Behavior of Consumers of FMCG Sector Companies in Lucknow. Amity Global Business Review, 2(12), 46-50.

42. Kontautienė, R. 2016. Imonių socialinė atsakomybė kaip konkurencingumo veiksnys ekonomikos nuosmukio laikotarpiu: naujosios demokratijos atvejis. Daktaro disertacija. Kaunas: Kauto technologijos universitetas.

43. Korsakienè, R., Marcinkevičius, S. 2013. Filantropinè įmonès atsakomybè ir veiklos rezultatai: gamybos įmonès atvejis. Verslas: teorija ir praktika, 14(2), 131-139. 
44. Kovaliov, R., Šubonytè, J., Simanavičienè, Ž. 2010. Makroekonominès verslo aplinkos įtaka ISA plètrai. Ekonomika ir vadyba. Kaunas: KTU, Nr. 15.

45. Lee, H., Lancendorfer K. M., Reck, R. 2011. Perceptual Differences in Corporate Philanthropy Motives: a South Korean Study. International Journal of Nonprofit and Voluntary Sector Marketing, 17(1), 33-47.

46. Lee, M., E., Park, S. Y., Lee, H. J. 2013. Employee Preception of CSR Activities: Its Antecedents and Consequences. Journal of Business Research 66, 1716-1724.

47. Leitonienè, S., Šapkauskienè, A. 2016. Information Disclosure in Corporate Social Responsibility Reports. The Case of Lithuanian Companies. Zeszyty Teoretyczne Rachunkowośc, 88(144), 73-85.

48. Lin, C. P. 2010. Modeling Corporate Citizenship, Organizational Trust and Work Engagement based on Attachment. Theory, Business Ethics 94, 517-531.

49. Majer, M. 2013. The Practice of Mining Companies in Building Relationships with Local Communities in the Context of CSR formula. Journal of Sustainable Mining, 12 (3), 38-47.

50. Navarro-Galera, A., Ruíz-Lozano, M., de los Ríos-Berjillos, A. and Tirado-Valencia, P. 2014. Corporate Social Responsibility in Local Government in the United Kingdom and Ireland. Innovar Journal, vol. 24, no. 54, pp. 89-105.

51. Oshin-Martin, M. 2017. Corporate Social Responsibility: Johnson \& Johnson Creating Community Relations and Value through Open Social Innovation and Partnership across SubSaharan Africa. Corporate Social Responsibility, Sustainability, and Ethical Public Relations 167-197.

52. Pilinkienè, V., Velykytė, E., Dekerytė, G., Imbrazas, A. 2018. The Assessment of a Socially Responsible Company: an Example of the KTU Faculty of Economics and Business. Social Education / Smart Education as a Condition of Society Quality 2018, t. 49, Nr. 2, p. 49-65 / Vol. 49, No. 2, pp. 49-65, 2018.

53. Pollitt, C., Bouckaert, G. 2011. Public Management Reform: A Comparative Analysis - New Public Management, Governance, and the Neo-Weberian State. Oxford University Press.

54. Potašinskaite, M., Draugelytė, A. 2013. İmonių socialinès atsakomybès dedamujų fragmentiškas naudojimas Lietuvoje. Scientific Journal, 35(3), 423-431.

55. Rahman, S. 2011. Evaluation of Definitions: Ten Dimensions of Corporate Social Responsibility. World Review of Business Research, 1, (1), 166-176.

56. Raipa, A. 2011. Viešojo valdymo evoliucija XX-XXI a. sandūroje: socialinė dimensija. III. Sociologija ir socialinè politika, Socialinis darbas, Nr. 10(1).

57. Raipa, A. 2014. Iššūkiai valstybès tarnybai naujojo viešojo valdymo kontekste. Viešoji politika ir administravimas. 2014, T. 13, Nr. 4, p. 545-556. Mykolo Romerio universitetas.

58. Rybnikova, I., Toleikienè, R. 2015. Vadovų itaka socialinei organizacijų atsakomybei viešojo sektoriaus kontekste. Socialinè atsakomybè versle ir viešajame sektoriuje (24-72). Šiauliai: Šiaulių universiteto bibliotekos Leidybos skyrius.

59. Rodeia, G. R. N. M. 2017. The Power of CSR and its Implications on Employee's Satisfaction, Motivation and Happiness at Work: the Case of Starbucks. Dissertation. Universidade Católica Portuguesa.

60. Romi, A., Cook, A. K., Dixon-Fowler, R. H. 2018. The Influence of Social Responsibility on Employee Productivity and Sales Growth: Evidence from Certified B Corps. Sustainability Accounting, Management and Policy Journal, 9 (4), 392-421.

61. Scherer, A. G., Palazzo, G. 2011. The New Political Role of Business in a Globalised World: A Review of a New Perspective on CSR and its Implications for the Firm, Governance, and Democracy. Journal of Management, 48(4), 899-931.

62. Seiliūtè, J. 2013. Socialinès atsakomybès įtvirtinimo potencialo verslo organizacijose vertinimas. Daktaro disertacija, Vilnius: Vilniaus universitetas.

63. Skačkauskienè, I. ir Valentinovič, J. 2016. Apmokestinimo teisingumo ir socialinès atsakomybès Lietuvoje tyrimas. Mokslas - Lietuvos ateitis, 8(2), 171-181. 
64. Stachowicz-Stanusch, A., Mangia, G., Amann, W. Tomo, A. 2017. Corporate Social Irresponsibility: Individual Behaviors and Organisational Practices. Do Individual Behaviors Influence Corporate Socially Irresponsible Practices? Charlotte, NC.: Information Age Publishing, Inc.

65. Stubbs, W., Higgins, C., Milne, M. 2013. Why Do Companies Not Produce Sustainability Reports? Business Strategy and the EnvironmentBus. Strat. Env. 22, 456-470 (2013).

66. Šimanskienė, L., Paužuolienè, J. 2010. Imonių socialinès atsakomybès svarba Lietuvos organizacijoms. Management Theory and Studies for rurl Business and Infrastructure Development, 20 (1).

67. Šimanskienė, L., Paužuolienè, J. 2015. Imonių socialinės atsakomybės svarba darniam organizacijų vystymui. Socialinė atsakomybė versle ir viešajame sektoriuje. Mokslo studija. Šiauliai: ŠU leidykla, p.11-23.

68. Tarptautiniai prekybos rūmai (Iternational Chamber of Commerce). 2010. Policy and Business Practices. http://www.iccwbo.org/about-icc/organization/policy-and-businesspractices/ [2020-03-15].

69. Tripathi, A., Bains, A. 2013. Evolution of Corporate Social Responsibility: a Journey from 1700 BC till 21st Century. International Journal of Advanced Research, 1(8), $788-796$.

70. Unterberger, M., Vešovič, P., Mostarac, K., Šarac, D., Ožegovič, S. 2018. Three-Dimensional Corporate Social Responsibility Model of a Postal Service Provider. Traffic Policy Review, 3(30), 349-359.

71. Weber, M. 2008. The Business Case for Corporate Social Responsibility: a Company-Level Measurement Approach for CSR. European Management Journal, 26, 247-261. doi: 10.1016/j.emj.2008.01.006

72. Wei Wang, W., Fu, Y., Qiu, H., Moore, H. J., Wang, Z. 2017. Corporate Social Responsibility and Employee Outcomes: a Moderated Mediation Model of Organizational Identification and Moral Identity. Organisational Psychology Journal, July 5.

73. Welford R. 2005. Corporate Social Responsibility in Europe, North America and Asia. Journal of Corporate Citizenship, 17, 33-52.

74. Žičkienè, S., Kavaliauskienè, Ž. 2015. Polemika socialinès atsakomybès klausimais. Socialinè atsakomybè versle ir viešajame sektoriuje (24-72). Šiauliai: Šiaulių universiteto bibliotekos Leidybos skyrius.

\title{
Gita Lasytè
}

\section{Socialiai atsakingas organizacijos valdymas viešajame sektoriuje}

\author{
Anotacija
}

Šiame straipsnyje siekiama išnagrinèti teorines socialiai atsakingo organizacijos valdymo prielaidas viešajame sektoriuje. Valstybès institucijose organizacijos socialinè atsakomybė yra ganètinai naujas reiškinys. Todėl darbe yra aptariama socialinès atsakomybės ir Naujojo viešojo valdymo sąveika. Straipsnyje remiamasi prielaida, kad viešojo sektoriaus teikiamų viešųų gèrybių ir viešujų paslaugų valdymo principai savo turiniu labai artima socialinès atsakomybès koncepcijai. Viešojo valdymo proceso siekis yra efektyvumas ir veiksmingumas ne tik viešojo administravimo institucijose, bet ir gerovès visuomenès kūrime. Atsižvelgiant $\mathfrak{i}$ tai, naujasis viešasis valdymas remiasi socialinès atsakomybès principais. Panašumų tarp naujojo viešojo valdymo ir socialinès atsakomybès galima ịžvelgti per vertybių, procesų bei elementų supratimą. Pagrindiniai abiejų normatyvai yra atskaitomybè, atvirumas, efektyvumas, atsakingumas, atitikimas procesinėms normoms, valdžios 
padalijimas (suinteresuotujų šalių įtraukimas). Straipsnyje taip pat yra aptariama organizacijos socialinès atsakomybės samprata, bruožai bei pateikiama reiškinio kritika.

Gita Lasyte - PhD candidate in the field of management of the Faculty of Public Governance at Mykolas Romeris University.

E-mail:_gita@mruni.eu

Gita Lasyte - Mykolo Romerio universiteto Viešojo valdymo fakulteto doktorantė.

El.paštas: gita@mruni.eu

This article is an Open Access article distributed under the terms and conditions of the Creative Commons Attribution 4.0 (CC BY 4.0) License (http://creativecommons.org/licenses/by/4.0/ ). 